\title{
Assessing the Influence of Traffic Impact Assessments on Land Use Development and Decision Making
}

\author{
Jayantha Withanaarachchi, Sujeeva Setunge, Shamas Bajwa \\ RMIT University, Melbourne, Australia
}

\begin{abstract}
Rapid urbanisation and land use planning in cities and countries worldwide have an impact on traffic related risks to society as a whole. Strategic planning decisions made during land use development approvals can affect the performance of transport infrastructure significantly impacting on community safety. One major contributor to the decision-making process is Traffic Impact Assessment (TIA) undertaken prior to development approval. The content of each TIA process differs according to the type of development and its geographical location. The paper presents a brief overview of the strategic decision-making process adopted in Australia in land use development approvals. Using a selected case study area, the importance of the TIAs to the decision-making process is demonstrated. Further, the paper presents the observed differences between the facts presented in TIAs completed by four different consultants and the influence of the new development in the community safety. Traffic records after the new development indicate that the accidents have almost doubled after the new development. It is noted that the current TIA process requires significant changes to ensure that the influence of the land use development decisions are captured correctly to ensure informed strategic decision-making. A set of recommendations to overcome the shortcomings of existing planning and TIA designing process is presented.
\end{abstract}

Keywords: Traffic Impact Assessment (TIA), land use development, traffic accidents

\section{Impact of Land Use Development}

Informal land use developments are seen as the main problem that is causing most of the traffic congestion, road safety, and environmental pollution issues. The existing land use development approval decision-making strategies and policies create the present day transport issues. It is important to understand the processes and decision-making to be able to improve and land use planning and transport planning integration between the two authorities. In many countries there are many authorities administering land use development components, such as land use allocation, land use strategy formations, and land use conversions from rural or farmland to residential or commercial separate to transport planning. Transport planning is done by the State transport authorities. Due to this each responsible authority follows their own set of strategies and policies. Integration between authorities is not a frequent practice. This break up of coordination and planning between agencies leads to many difficulties, such as administration and implementation of required critical transportation

Jayantha Withanaarachchi, Ph.D. candidate, School of Civil, Environmental and Chemical Engineering, RMIT University.

Sujeeva Setunge, Professor, Head of Discipline, Civil Engineering, RMIT University.

Shamas Bajwa, Program Director, School of Environmental Engineering, RMIT University.

Correspondence concerning this article should be addressed to Jayantha Withanaarachchi, 59 Dandarriga Drive, Clifton Springs,3222, Victoria, Australia. E-mail: jayanthaw@geelongcity.vic.gov.au. 
infrastructure. Therefore it is required to carry out holistic planning to ascertain the true dynamics within cities and how authorities could provide the infrastructure during land use development processes.

Transport system upgrades or additional network improvements are needed to provide for urban expansion. One of the main issues that affect this is fragmental or ad-hoc residential and commercial developments planned without giving proper consideration to strategic transport planning. Transport planning and coordination should be considered at all levels of government (national, state, and local) and at international level. Proper of strategic planning will improve connectivity between these levels of transport system networks. The transport system has its own complexities. Governments and countries rely on the transport systems for promoting goods and services for economic gains. For the city decision-makers, to arrive at proper decisions, the tools that are used need to be reliable and accurate. It is recognised that it is important to understand the total dynamics of adjacent transport networks and connections, before any decisions are taken to approve major developments, which will change the travel patterns and have an impact on the network.

\section{Research Framework}

Strategic transport planning decisions taken during the planning stage of transport infrastructure will have numerous impacts on the long-term performance of transport infrastructure as well as the resilience of communities during a disaster. A research project conducted at RMIT University in collaboration with the City of Greater Geelong Council in Victoria, Australia, aimed to identify gaps in the strategic decision-making process which contributes to risk and resilience of performance of transport infrastructure over the life cycle of infrastructure. Three different areas of strategic planning which contribute to the design of transport infrastructure are identified as: transportation corridor planning, road design, and land use development approvals. The process relied heavily on recorded case studies of failure and the gaps observed in the strategic planning process of transport infrastructure. The overall research framework is shown in Figure 1.

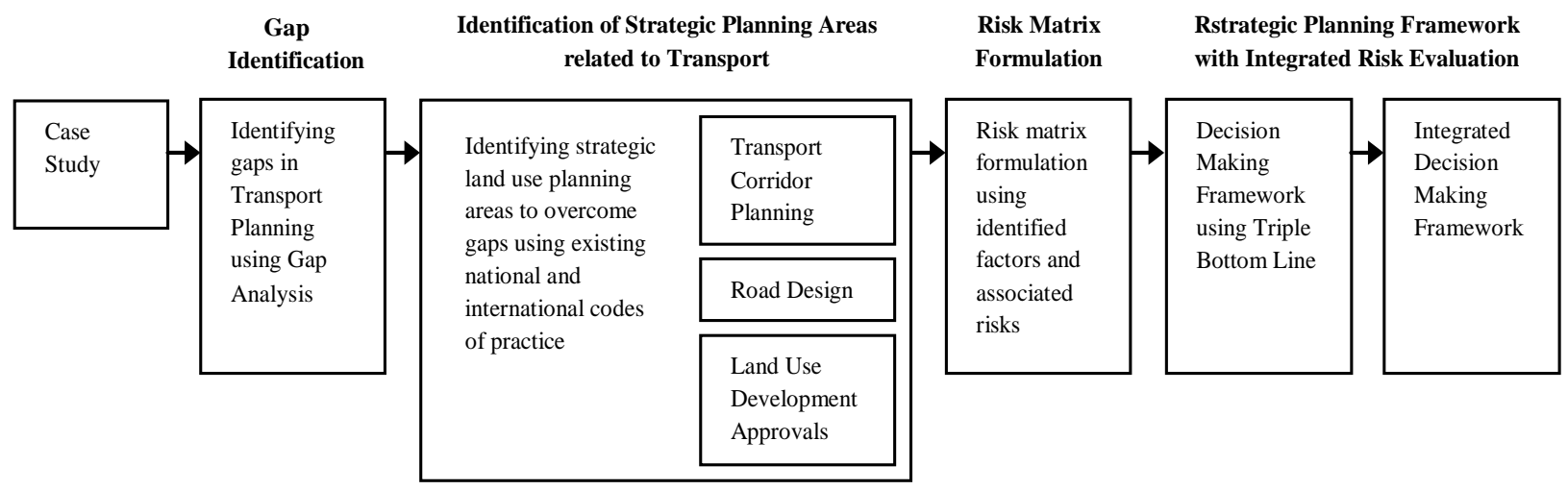

Figure 1. Overall research framework.

This paper focuses on the land use development approval processes and Traffic Impact Assessment (TIA) which provides evidence to take decisions during application approval stages. The case studies are used to highlight the importance of TIA and its effect on society due to new developments.

\section{Importance of Transport Networks}

Modern supply chains due to concepts such as "agility”, “just in time”, and "lean” are increasingly relying on efficient transport infrastructure. The reliance on the transport network is immense. Any negative impact on 
the transport network has an enormous impact on supply chains and critical infrastructure functionalities. Transport network reliability is important and has the ability of the transport system to provide the expected level of service quality, upon which users have organised their activities (OECD/ITF, 2010). The transportation system is a key critical infrastructure component. In most countries the road and transport infrastructure are considered as a national priority. The transport system is designed to cater to the community needs and provide accessibility to goods and services and also provide "escape routes" during disasters. The travel pattern of movement in a network may change dramatically after a disaster, due to people evacuating an area or people entering an area to render assistance (Nicholson \& Du, 1997). The transport system supports economic growth and helps sustain GDP in developed countries and reduces poverty in developing countries and designed to cater to community needs and provide reliability and accessibility to critical infrastructure (CI) service. Transports networks need to be improved as well as new networks need to be constructed to cater to the growing urban population and to improve social status of people.

Road networks play an important role by connecting cities, townships, and countries providing services for different configurations of CI systems. These networks also facilitate the provision of other CI services which are located within road reserves. Gas, water, sewerage, electricity, telecommunication, and fibre optic cables are laid underground as well as above ground, which depend heavily on the transportation network to maintain their functionality. Many local governments in Australia have their own typical road reserve layouts similar to Figure 2. Road reserve is used by utilities such as telephone, water, telecommunication, internet, electricity, gas, lighting, and drainage uses road reserves for accessibility and trees planted along the shoulders to provide aesthetics and/or shade. Most of the CI services are located underground at different depths and at different offsets from the road reserve edge.

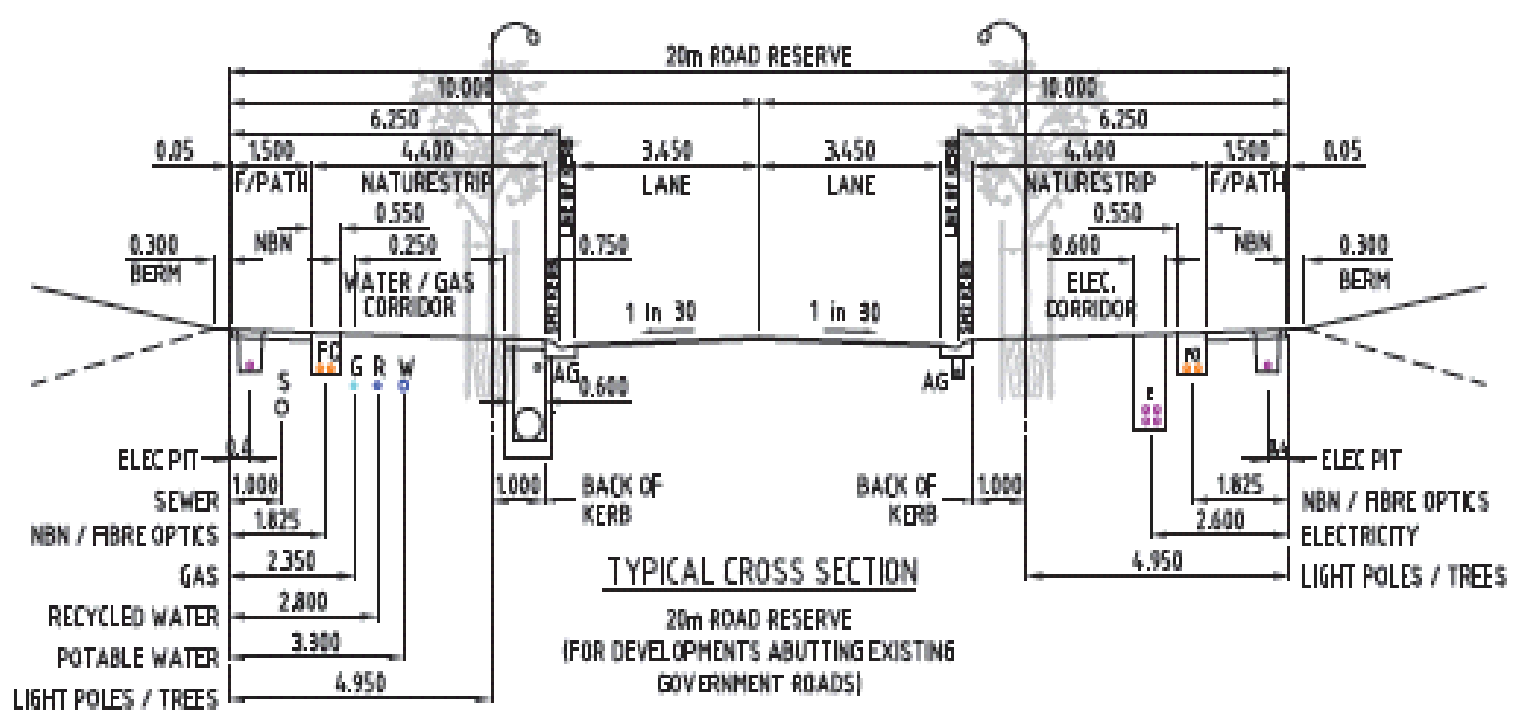

Figure 2. Service utilities within road reserve. Source: City of Greater Geelong, IDM Infrastructure design Manual-Standard Drawing SD 605.

\section{Transport Issues}

Transport movements and type of vehicle combinations and available road space for vehicles plus transport infrastructure dictates all the conditions, such as environmental pollution due to air pollution or road 
safety or travel times and reliability. The Australian Government report has estimated that economic costs due to congestion in the city of Sydney is $\$ 3.5$ billion in 2005 and will rise to $\$ 7.8$ billion in 2020 (Edwards \& Smith, 2006).

\section{Decision Making in Land Use Planning}

\section{Land Use Development Approval in Australia, Victoria}

All land use planning processes and decisions have an impact on society and communities and affect peoples' livelihood and amenity and any consequences of planning decisions affect the society for a long time. In Victoria, Australia, the Planning and Environment Act 1987 (The Act) is the legislative basis of the planning system. The purpose of the Act is: "To establish a framework for planning the use, development, and protection of land in Victoria in the present and long-term interests of all Victorians” (Auditor General's Report, 2008). Council Plan and the Municipal Strategic Statement provide direction about the strategic objectives for land use planning within the municipality. Strategic planning develops strategic objectives and policies and facilitates Council to achieve Local Planning policies and objectives. Planning process decisions such as new public transport, new shopping centre, location of parks, bike paths, and new road layouts have an effect on societies. These planning decisions influence communities on how they go about their day-to-day things, like getting to work, schools, shopping and visiting and most importantly providing escape routes during disasters. A planning permit is a legal document that gives permission for a use or development on a particular piece of land. And every municipality in Victoria has its own planning scheme. It sets out the objectives, strategies, policies, and controls for the use, development, and protection of land in the present and long-term interests of all Victorians. As shown in Tables 1 and 2, over 50,000 permits are issued in Victoria each year and 300-400 planning scheme amendments are approved per year (see Tables 1 and 2) in Victoria.

Table 1

Planning Permit Application

\begin{tabular}{llll}
\hline \multicolumn{2}{l}{ Number of planning permit applications in Victoria } & \\
\hline Victoria & $2004-2005$ & $2005-2006$ & $2006-2007$ \\
Melbourne metropolitan & 53,260 & 50,667 & 49,587 \\
Rural/Regional & 33,271 & 32,117 & 31,289 \\
\hline
\end{tabular}

Table 2

Planning Scheme Amendments

\begin{tabular}{ll}
\hline Number of approvals of planning scheme amendments in Victoria \\
\hline Year & Number of amendments \\
\hline $2004-2005$ & 332 \\
$2005-2006$ & 432 \\
20062007 & 405 \\
\hline
\end{tabular}

Note. Source: Auditor General’s Report, 2008.

There are two main types of planning:

Strategic planning — provides the broad policy frameworks for specific land use developments;

Statutory planning -includes developing and amending planning schemes, processing applications for planning permits (see Figure 3). 


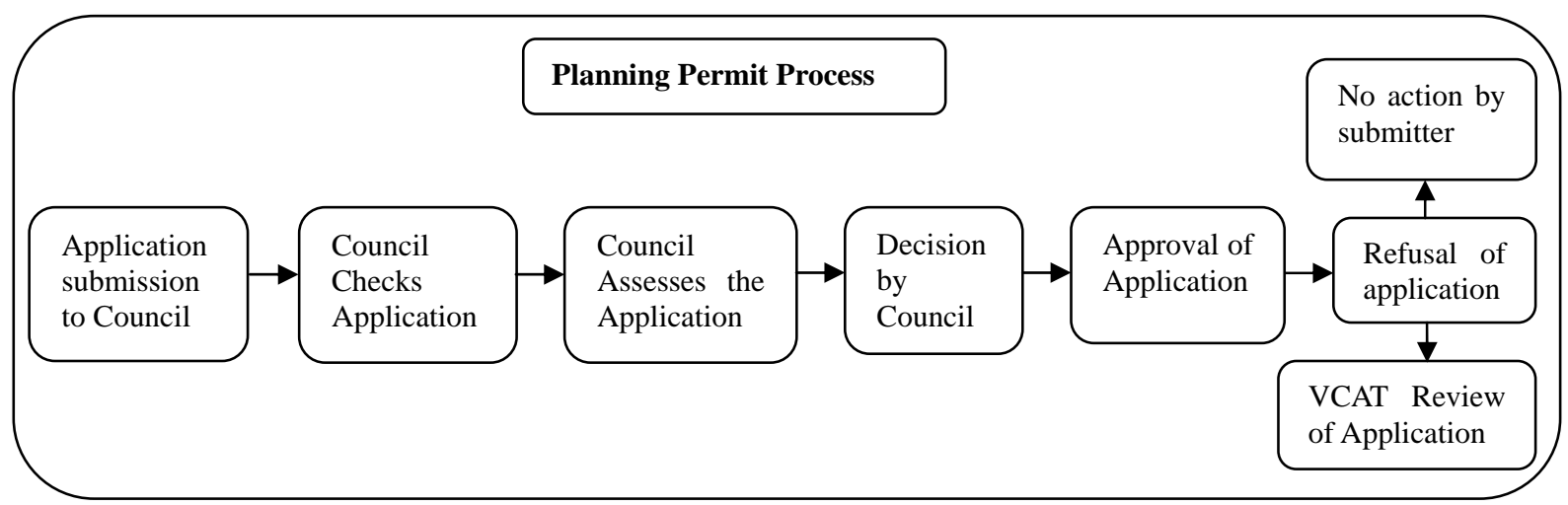

Figure 3. Planning permits flow path framework.

State Planning Policy Framework (SPPF) — Prepared by the State Government/Minister for planning. This sets out state planning policies (e.g., metropolitan development, settlement, environment, housing, economic development, infrastructure, subdivision, gaming, design, and built form). Every planning scheme includes the SPPF.

Local Planning Policy Framework (LPPF) — Prepared by the Council and approved by the Minister for planning. The LPPF must be consistent with the SPPF and contains the Municipal Strategic Statement (MSS) and local planning policies.

MSS-The MSS is the foundation of the strategic planning framework and provides the basis of planning decisions in a municipality and contains council's strategic planning, land use and development objectives and strategies for achieving these objectives.

VCAT (the Victorian Civil and Administrative Tribunal)—The Council's decision about a planning permit application may not be final. VCAT has independently reviewed decisions made by Councils about planning permit applications and other planning matters. VCAT functions in accordance with the Victorian Civil and Administrative Tribunal Act 1998. The State Government appoints VCAT members who are qualified legal practitioners, planners, and other specialists. The Minister for planning is not responsible for VCAT. The Tribunal's decision may indicate an ambiguity about the interpretation or application of a local policy in the planning scheme or a gap or uncertainty in the MSS. The Tribunal's decision is final unless there is a question of law that can be taken to the Supreme Court. Legal advice is essential before following this course of action.

\section{Components of Victorian Planning Scheme Framework}

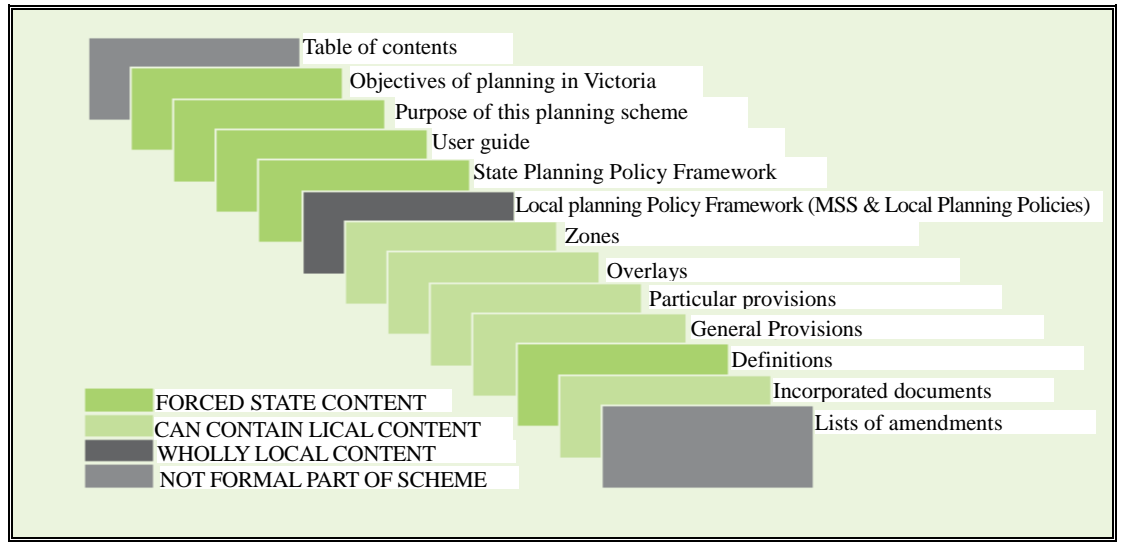

Figure 4. Planning Scheme Framework. Source: Land Use Planning in Victoria—A Councillor’s Guide, p. 26. 


\section{Auditor General's Findings-Australia-Victoria's Land Use Planning Process}

The Victorian Auditor-General, stated in the "Victoria's Planning Framework for Land Use and Development Report, 2008” that "Planning decisions affect the lives of all Victorians and they can have a significant impact on local communities, the environment, key industries and the broader economy". And he further stated that proper planning processes are essential to prevent inappropriate land use and development and all decision-making process should comply with the Planning and Environmental Act 1987 (Auditor General's Report, 2008). The Victoria's planning system (see Figure 4) has been subject to continuous reform since the early 1990s. As part of these reforms, the Act was amended in 1996 to introduce the Victoria Planning Provisions (VPP) and establish new format planning schemes with a strategic and performance-driven focus to reduce administrative costs and increase efficiency of the planning system (Auditor General's Report, 2008). The report further stated that the existing Victoria's framework for controlling land use and development is complex and unclear and the existing arrangements do not allow for comprehensive measurement and monitoring of the overall performance of the planning system, measure the effectiveness and efficiency of advisory and statutory support services primarily provided to councils (Auditor General’s Report, 2008).

\section{TIA}

All commercial and non-commercial (residential) developments generate traffic movements. This generation of traffic depends on the location and size of the development and has an impact on the surrounding areas and on the existing local and arterial transport network. Most of the time it creates traffic congestion, air pollution, and safety issues in public. Therefore for the decision-makers, to take decisions regarding new developments, Traffic impact analysis or assessment is used as a tool to guide them to assess each development. The TIA report should be requested by local or state authority, responsible for making the decisions and should be prepared by an industry qualified traffic or transport engineer. The report should be an impartial report, highlighting all the facts, how it will impact on the surrounding road network and also identify existing transport network improvements, funding sources, infrastructure improvements to improve safety, ways to maintain a level of safety (LOS), new road connections, impact on amenity and safety. The TIA's should be comprehensive in all ways to address the issues. If the report contains all the relevant information, then it is easier for the decision-makers to agree on remedial measures than the report being interpreted differently. In Table 7, the components of a TIA are shown.

\section{Case Study Analysis}

\section{Land Use Development of a Shopping Center in West Geelong, Victoria, Australia}

The reason of this case study (see Figure 5 and Table 3) was chosen is that four traffic engineering consultants were engaged in this one development. Two consultants prepared the reports for the developer, one consultant peer reviewed the report and the other consultant peer reviewed the previous reports for the independent panel report. Normal practice is one traffic consultant will prepare one report to Council. The four reports produced due to issues raised by resident groups and therefore Council decided that it should be reviewed by an independent panel. The proposal is to rezone land from Industrial 1 Zone (IN1Z) to Mixed Use Zone (MUZ), Residential 1 Zone (R1Z), and Business 4 Zone (B4Z). 


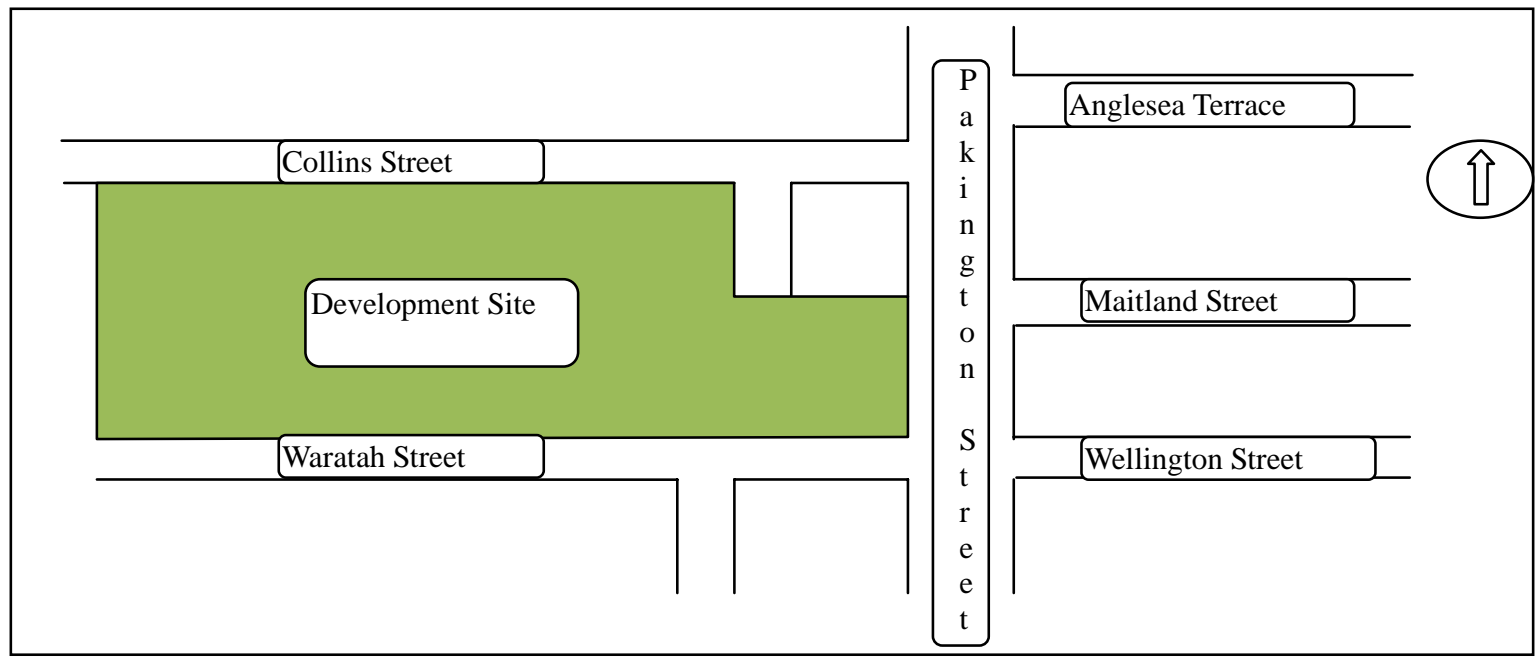

Figure 5. Proposed shopping center area.

The proposal requires a planning scheme amendment (rezoning) and a planning permit application to proceed under the Planning and Environmental Act 1987. It was considered to be consistent with the SPPF and LPPF by the developer, in that it would encourage the consolidation and development of activity centres for a wide range of commercial and community users.

Table 3

Components of the Development

\begin{tabular}{ll}
\hline Components of the development & \\
\hline Supermarket $=3,600 \mathrm{~m}^{2}$ gross leasable floor space & Car parking spaces $=320$ spaces \\
Office $=450 \mathrm{~m}^{2}$ & Vehicle access points $=4$ \\
Specialty shops $=2,100 \mathrm{~m}^{2}$ & Store/Display area $=140 \mathrm{~m}^{2}$ \\
4 two-storey dwellings & \\
\hline
\end{tabular}

Table 4

Accidents Numbers According to Distance From the Development

\begin{tabular}{|c|c|c|c|c|c|c|c|c|c|c|c|c|}
\hline \multirow[b]{2}{*}{ C96 } & \multicolumn{4}{|c|}{$400 \mathrm{~m}$ radius } & \multicolumn{4}{|c|}{$600 \mathrm{~m}$ radius } & \multicolumn{4}{|c|}{$1,000 \mathrm{~m}$ radius } \\
\hline & $\begin{array}{l}\text { Fatal } \\
=1\end{array}$ & $\begin{array}{l}\text { Serious } \\
\text { injury = } 2\end{array}$ & $\begin{array}{l}\text { Other } \\
\text { injury }=3\end{array}$ & Non-Injury $=4$ & $\begin{array}{l}\text { Fatal } \\
=1\end{array}$ & $\begin{array}{l}\text { Serious } \\
\text { injury }=2\end{array}$ & $\begin{array}{l}\text { Other } \\
\text { injury }= \\
3\end{array}$ & Non-Injury $=4$ & $\begin{array}{l}\text { Fatal } \\
=1\end{array}$ & $\begin{array}{l}\text { Serious } \\
\text { injury = } 2\end{array}$ & $\begin{array}{l}\text { Other } \\
\text { injury } \\
=3\end{array}$ & Non-Injury $=4$ \\
\hline 2005 & 0 & 0 & 2 & 0 & 0 & 0 & 4 & 0 & 0 & 4 & 10 & 0 \\
\hline 2006 & 0 & 2 & 0 & 0 & 0 & 4 & 2 & 0 & 0 & 1 & 5 & 0 \\
\hline 2007 & 0 & 2 & 0 & 0 & 0 & 3 & 0 & 0 & 0 & 4 & 6 & 0 \\
\hline 2008 & 0 & 4 & 2 & 4 & 0 & 3 & 3 & 5 & 0 & 7 & 10 & 12 \\
\hline Total & $\mathbf{0}$ & 8 & 4 & 4 & $\mathbf{0}$ & 10 & 9 & 5 & $\mathbf{0}$ & 16 & 31 & 12 \\
\hline 2009 & 0 & 0 & 2 & 4 & 0 & 2 & 3 & 23 & 0 & 4 & 17 & 21 \\
\hline 2010 & 0 & 1 & 2 & 7 & 0 & 2 & 11 & 12 & 0 & 1 & 19 & 18 \\
\hline $2011^{*}$ & 0 & 1 & 2 & 7 & 0 & 1 & 5 & 5 & 0 & 2 & 3 & 7 \\
\hline Total & $\mathbf{0}$ & 2 & 6 & 18 & $\mathbf{0}$ & 5 & 19 & 40 & $\mathbf{0}$ & 7 & 39 & 46 \\
\hline
\end{tabular}

Note. ${ }^{*}$ Accident data up to June 2011. Bold figures mean totals.

Council assesses the application and decides on one of the three options: to abandon the amendment, change the amendment to suit the development proposal or refer to an independent panel to review the application. In this instance Council decided to give the application to an independent panel to review and 
prepare the report. There are existing conditions such as Design and Development Overlay 14 (DDO 14) and an Environmental Audit Overlay (EAO) for the site. DDO 14 applies to building height of $7.5 \mathrm{~m}$. Main concerns raised by residents were-economic impact, health impact, amenity impact, and heritage impact. Issues identified traffic movement and safety issues, inconsistency with the urban design guidelines, traffic impact on road network, lack of open space, and appropriateness of zone and land use. The developer is responsible for all new infrastructures, including services, signals, road works, and intersection treatments.

\section{Accident Data Analysis}

The above data shows all the accidents that occurred between 2005 and 2011 (see Table 4). Table 5 shows that vehicle-vehicle accidents have increased within the investigated area. Table 6 shows total accidents have increased over the development year. However, in the $400 \mathrm{~m}$ radius the accidents before and after have stabilised to 10 accidents (see Figure 6).

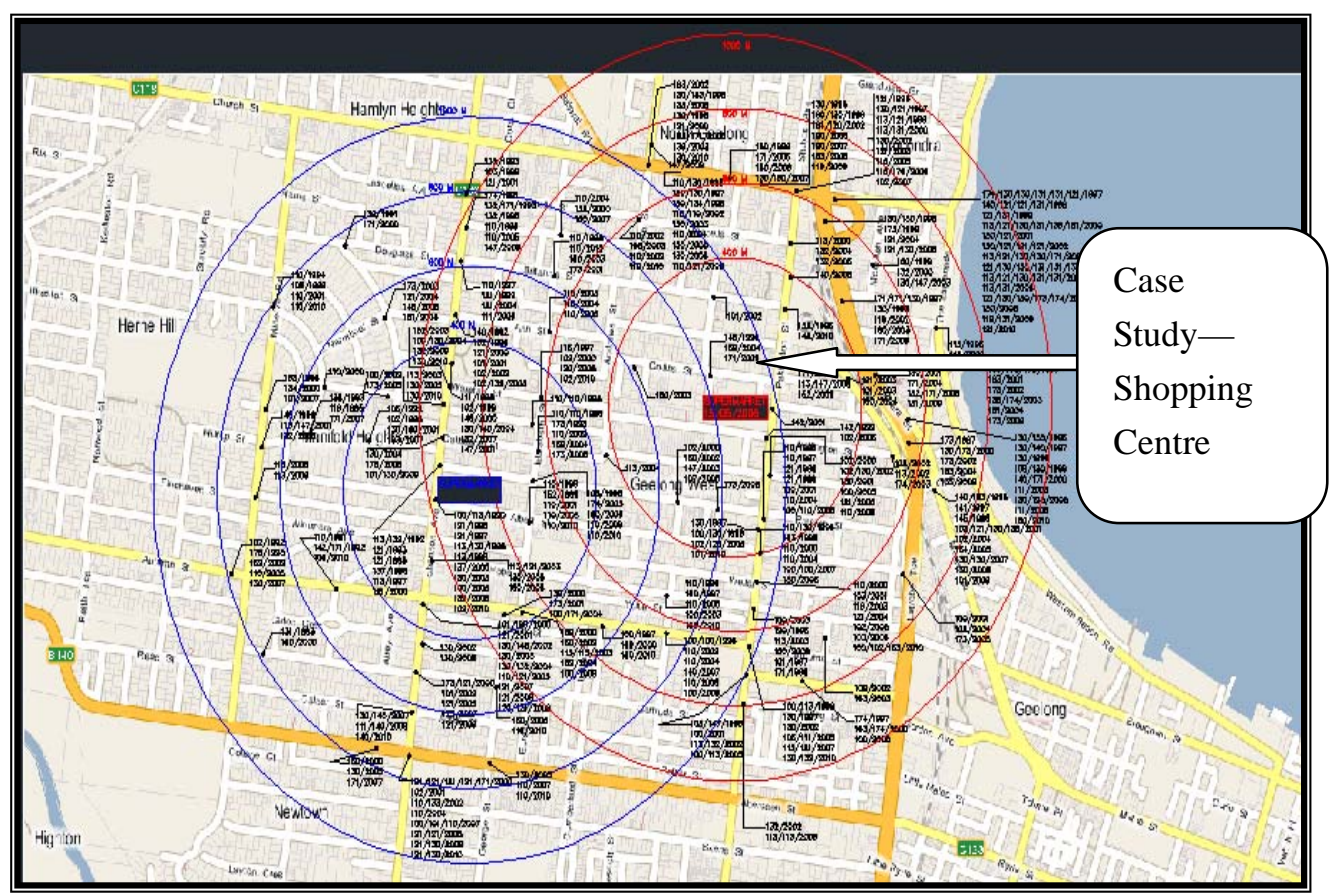

Figure 6. Accident data showing DCA’s and radius.

Table 5

Pedestrian Related and Vehicle/Vehicle Accident Analysis

\begin{tabular}{|c|c|c|c|c|c|c|c|c|c|}
\hline \multicolumn{10}{|c|}{ Definitions for Classifying Accidents (DCA) Analysis-Radius } \\
\hline \multirow{2}{*}{ Year } & & \multicolumn{4}{|c|}{ Pedestrian related accidents } & \multicolumn{4}{|c|}{ Vehicle/Vehicle related accidents } \\
\hline & & $400 \mathrm{~m}$ & $600 \mathrm{~m}$ & $1,000 \mathrm{~m}$ & Total & $400 \mathrm{~m}$ & $600 \mathrm{~m}$ & $1,000 \mathrm{~m}$ & Total \\
\hline \multirow{4}{*}{$\begin{array}{l}\text { Before } \\
\text { development }\end{array}$} & 2005 & 2 & 1 & 3 & 6 & 0 & 3 & 11 & 14 \\
\hline & 2006 & 0 & 1 & 1 & 2 & 2 & 5 & 6 & 13 \\
\hline & 2007 & 2 & 0 & 3 & 5 & 0 & 3 & 7 & 10 \\
\hline & 2008 & 1 & 0 & 5 & 6 & 11 & 11 & 26 & 48 \\
\hline \multirow{3}{*}{$\begin{array}{l}\text { After } \\
\text { development }\end{array}$} & 2009 & 1 & 3 & 6 & 10 & 7 & 25 & 38 & 70 \\
\hline & 2010 & 2 & 3 & 4 & 9 & 8 & 21 & 27 & 56 \\
\hline & $2011^{*}$ & 0 & 0 & 1 & 1 & 10 & 11 & 11 & 32 \\
\hline
\end{tabular}

Note. ${ }^{*}$ Accident data up to June 2011. 
Table 6

Accident Numbers-Before and After Development

\begin{tabular}{|c|c|c|c|c|c|c|c|c|c|}
\hline \multicolumn{10}{|c|}{ Serious and other accidents_-Radius } \\
\hline \multirow{2}{*}{$\begin{array}{l}\text { Status of } \\
\text { development }\end{array}$} & \multirow{2}{*}{ Year } & \multicolumn{4}{|c|}{ Serious injury accidents } & \multicolumn{4}{|c|}{ Other and non-injury accidents } \\
\hline & & $400 \mathrm{~m}$ & $600 \mathrm{~m}$ & $1,000 \mathrm{~m}$ & Total & $400 \mathrm{~m}$ & $600 \mathrm{~m}$ & $1,000 \mathrm{~m}$ & Total \\
\hline \multirow{4}{*}{$\begin{array}{l}\text { Before } \\
\text { development }\end{array}$} & 2005 & 0 & 0 & 4 & 4 & 2 & 4 & 10 & 16 \\
\hline & 2006 & 2 & 4 & 1 & 7 & 0 & 2 & 5 & 7 \\
\hline & 2007 & 2 & 3 & 4 & 9 & 0 & 0 & 6 & 6 \\
\hline & 2008 & 4 & 3 & 7 & 14 & 6 & 8 & 22 & 36 \\
\hline \multirow{3}{*}{$\begin{array}{l}\text { After } \\
\text { development }\end{array}$} & 2009 & 0 & 2 & 4 & 6 & 6 & 26 & 38 & 70 \\
\hline & 2010 & 1 & 2 & 1 & 4 & 9 & 23 & 37 & 69 \\
\hline & $2011^{*}$ & 1 & 1 & 2 & 4 & 9 & 10 & 10 & 29 \\
\hline
\end{tabular}

Notes. Total accidents numbers according to distance from the development; ${ }^{*}$ Accident data up to June 2011.

\section{Traffic Generation Estimates Due to Development}
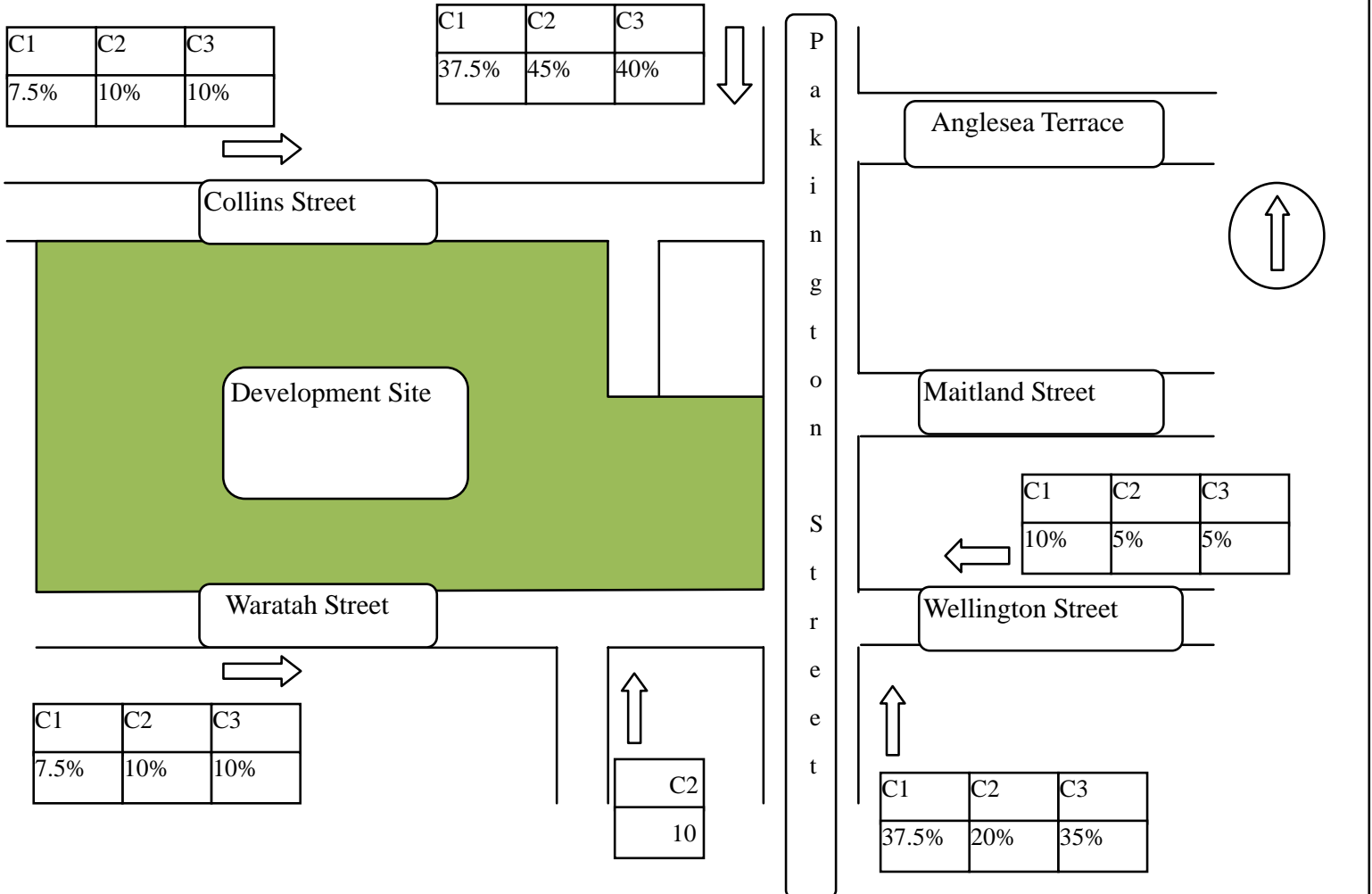

Figure 7. Traffic generation estimates by consultants. Notes. C1 = Consultant for developer; C2 = Consultant for developer; C3 = Consultant-Peer review for council; and C4 = Consultant—Peer review for independent panel (see full table in the Appendix A Figure A1).

Two of the four consultants discussed the traffic accidents close to the development site (see Figure 7). C1 consultant identified two accidents (1997-2001) and C4 consultant identified four accidents (2000-2004). Table 7 shows the main items that are in a TIA and how each consultant assessed the components. 
Table 7

Traffic Impact Assessment Process and Comparison

\begin{tabular}{|c|c|c|c|c|c|c|}
\hline \multicolumn{7}{|c|}{ Traffic impact assessment of consultant reports } \\
\hline \multirow{2}{*}{\multicolumn{2}{|c|}{ Traffic impact assessment main items }} & \multicolumn{4}{|c|}{ Traffic consultants } & \multirow{3}{*}{$\begin{array}{l}\text { Gaps identified in the } \\
\text { process }\end{array}$} \\
\hline & & $\mathrm{C} 1$ & $\mathrm{C} 2$ & C3 & C4 & \\
\hline Main item & Sub-item & \multicolumn{4}{|c|}{ Identified in report } & \\
\hline \begin{tabular}{|ll}
$\begin{array}{l}\text { Document } \\
\text { development }\end{array}$ & proposed \\
\end{tabular} & Audit development plans & Yes & Yes & Yes & Yes & Description varies \\
\hline \begin{tabular}{|lrr} 
Resolve & any & initial \\
problems & & with \\
designers & & \\
\end{tabular} & Audit development plans & Yes & Yes & No & No & $\begin{array}{l}\text { Only few issues } \\
\text { identified }\end{array}$ \\
\hline \begin{tabular}{|l}
$\begin{array}{l}\text { Identify area and } \\
\text { stakeholder affected }\end{array}$ \\
\end{tabular} & Describe existing and design year conditions & No & No & No & Yes & $\begin{array}{ll}\text { Only adjacent areas } \\
\text { identified }\end{array}$ \\
\hline \multirow{3}{*}{$\begin{array}{l}\text { Determine generated } \\
\text { traffic and modal split }\end{array}$} & Determine approach and departure directions & Yes & Yes & Yes & Yes & Partially addressed \\
\hline & Assign traffic to roads & Yes & Yes & Yes & Yes & Partially addressed \\
\hline & Determine where non-car traffic will go & Yes & No & No & No & \begin{tabular}{|lr} 
Only few & issues \\
identified
\end{tabular} \\
\hline \multicolumn{2}{|c|}{ Review limits of area affected } & Yes & No & No & No & $\begin{array}{ll}\text { Only adjacent areas } \\
\text { identified }\end{array}$ \\
\hline \multirow{2}{*}{$\begin{array}{l}\text { Access traffic } \\
\text { operation on roads }\end{array}$} & Assess traffic operation on site & Yes & Yes & Yes & Yes & \\
\hline & $\begin{array}{l}\text { Assess pavement impact, road safety impact } \\
\text { \& environmental impacts }\end{array}$ & Yes & Yes & Yes & Yes & \begin{tabular}{|l|l|} 
Only few \\
identified
\end{tabular} \\
\hline \multicolumn{2}{|c|}{ Determine required impact mitigating treatments } & Yes & Yes & Yes & Yes & $\begin{array}{l}\text { Only few } \\
\text { identified }\end{array}$ \\
\hline \multicolumn{2}{|c|}{ Obtain independent road safety engineering assessment } & - & - & - & - & Done by CoGG \\
\hline \multicolumn{2}{|c|}{ Document findings and recommendations } & Yes & Yes & Yes & Yes & Description varies \\
\hline
\end{tabular}

\section{Conclusions}

The analysis of the case study demonstrated that there are major gaps in the process.

The TIA is an important tool when assessing land use developments. In order to get a good decision on land use development, the TIA assessments have to be able to identify the true impact on environment, economy, and society. Variability of assessments indicates the flaws in the process and the need for standardised data as input to the analysis.

In the TIA analysis, the considered traffic volumes and the traffic generation rates of the development changed between the consultants. Traffic data should be collected and verified by the planning authority to avoid this misinterpretation.

One of the main amenity issues was the safety. Only two consultants discussed the accidents in the area. Others completely excluded accidents from the analysis. Analysis of traffic accidents should be a mandatory component of the process.

All the scope of the reports concentrated on the adjacent road network and not on the surrounding areas. It is accepted that each area is different and each development varies from one to another. The variations increase the complexity and the safety and risks to the community. On this occasion the used level of scoping did not capture the true numbers pertaining to road safety and its impact towards society.

The analysis demonstrated that accidents did not increase adjacent to the development, but increased further away due to traffic generation and flow towards the development. Further research is needed to ascertain the radius of the area to be covered in a given study. 


\section{References}

Auditor General's Report. (2008). Victoria's planning framework for land use and development Victorian auditor. Retrieved from http://download.audit.vic.gov.au/files/Framework_for_Land_Use_Report.pdf

Edwards, T., \& Smith, S. (2006). Transport problems facing large cities. Retrieved from http://www.parliament.nsw.gov.au/prod/parlment/publications.nsf/key/transportproblemsfacinglargecities/\$file/transportfinal index.pdf

Emberger, G., Pfaffenbichler, P., Jaensirisak, S., \& Timms, P. (2008). Ideal decision making processes for transport planning: A comparison between Europe and South East Asia. Transport Policy, 15, 341-349.

Johnstone, L., Kelly, I., \& Eccles, D. (2012). Land use planning in Victoria-A councillor's guide, Municipal Association of Victoria, Department of Sustainability and Environment. Retrieved from http://www.mav.asn.au

Kraas, F., Aggarwal, S., Coy, M., Heiken, G., de Mulder, E., Marker, B., ... Yu, W. I. (2005). Megacities-Our global urban future, earth science for society, prospectus for a key theme of the international year of planet earth. Retrieved from http://www.yearofplanetearth.org/content/downloads/Megacities.pdf

Nicholson, A., \& Du, Z. P. (1997). Degradable transportation systems: An integrated equilibrium model. Transportation Research Part B, 31(3), 209-223.

OECD/ITF. (2010). Improving reliability on surface transport networks. Retrieved from http://www.internationaltransportforum.org/pub/pdf/10reliability.pdf

Pearson, D. D. R. (2008). Crash statistics user guide, road crash statistics: Victoria. Retrieved from http://crashstat1.roads.vic.gov.au/crashstats/appendices.pdf

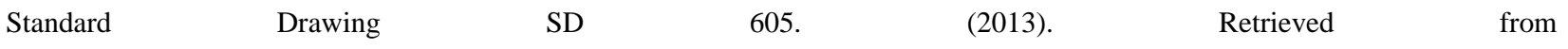
http://www.designmanual.com.au/files/IDM_Standard_Drawings_March_2013.pdf 
Appendix A

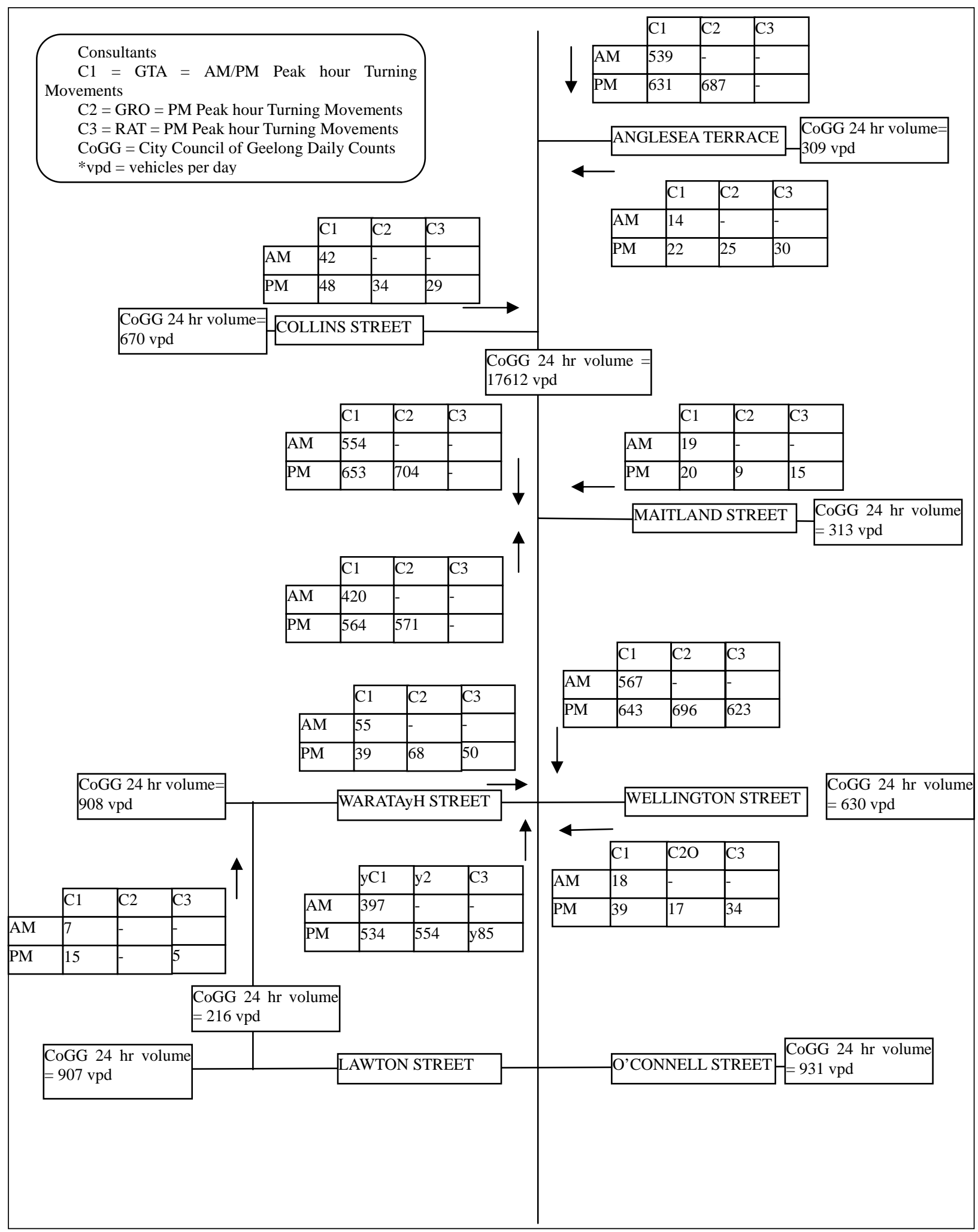

Figure A1. Existing AM/PM traffic volumes. 